(c) Мітюряєва-Корнійко І. О., Водяник А. А., Ліходієвський В. В., Понятовський В. А., Гнилоскуренко Г. В., Гречуха Є. О., Друзенко М. Г., Корнійко Є. Ю., 2017

УДК 616-018:616-093/-098.616.61-002

МІТЮРЯЕВА-КОРНІЙКО І.О., ВОДЯНИК А.А., ЛІХОДІЕВСЬКИЙ В.В., ПОНЯТОВСЬКИЙ В.А., ГНИЛОСКУРЕНКО Г.В., ГРЕЧУХА Є.О., ДРУЗЕНКО М.Г., КОРНІЙКО Є.Ю.

ЗАЛЕЖНІСТЬ ПАТОМОРФОЛОГІЧНИХ ЗМІН ПАРЕНХІМИ НИРКИ ВІД ЗДАТНОСТІ БАКТЕРІЙ ДО УТВОРЕННЯ БАКТЕРІАЛЬНИХ БІОПЛІВОК ПРИ МОДЕЛЮВАННІ ГОСТРОГО ПІЕЛОНЕФРИТУ НА ЛАБОРАТОРНИХ МИШАХ

\author{
MITIURIAEVA-KORNIJKO, I.O., VODIANYK, A.A., LIHODIEVSKYYV.V., PONYATOVSKIY, V.A., \\ GNILOSKURENKO, A.V., GRECHUKHA, Y.O., DRUZENKO, M.O., KORNIJKO, Y.Y.,
}

\title{
PATHOMORPHOLOGICAL CHANGES IN RENAL PARENCHYMA, AFTER MODELING OF ACUTE PYELONEPHRITIS IN MICE, DEPENDING ON THE ABILITY OF BACTERIA TO FORM BIOFILMS.
}

\author{
Національний медичний університет ім. О.О.Богомольця
}

Bogomolets National Medical University

Ключові слова: біоплівкоутворення, гострий пієлонефрит, паренхіма нирки.

Key words: biofilm formation, acute pyelonephritis, renal parenchyma.

Резюме. Инфекция мочевых путей является одной из самых распространенных инфекционных заболеваний, которое поражает людей любого возраста и пола. Целью нашего исследования стало изучение морфологических изменений при остром пиелонефрите в зависимости от способности к формированию биопленок штаммами бактерий.

Материалы и методы. Модель острого пиелонефрита воспроизводилась с помощью восходящего заражения лабораторных мышей клиническими изолятами E.coli с низкой способностью к биопленкообразованию (группа №1) и высокой способностью к образованию биопленок (группа №2), материал забирался на 7 день эксперимента, гистологические срезы анализировались в сравнении с контролем (группа №3).

Результаты. В группе № 1 наблюдалась лейкоцитарная инфильтрация мозгового вещества почки с наличием отека стромы. В группе №2 наблюдалась гиперинфильтрация всех отделов почки, вместе с наличием экстравазатов и выраженного отека стромы.

Обсуждение. Изменения выявленные в результате гистологического исследования могут свидетельствовать, что биопленкообразование приводит к неэффективному иммунному ответу, что в свою очередь приводит к повышенной вторичной альтерации.

Выводы. Биопленкообразование важный фактор патогенности микроорганизмов, который влияет на течение острого пиелонефрита.

Summary. Urinary tract infection is one of the most common infectious diseases that affects people of any age and sex. The purpose of our study was to determine morphological changes in acute pyelonephritis, depending on the ability of bacteria strains to form biofilms.

Materials and methods. The model of acute pyelonephritis was reproduced by ascending urinary infection model of laboratory mice with clinical isolates of E.coli with low biofilm formation ability (group \# 1) and high biofilm formation ability (group \# 2), the material was taken on day 7 of the experiment, histological sections were analyzed in comparison with control (group \# 3).

Results. In group \# 1, leukocyte infiltration of the medulla of the kidney with the presence of edema of the stroma was observed. In group \# 2, hyperinfiltration of all parts of the kidney was observed, together with the presence of extravasates and severe edema of the stroma.

Discussion. Changes revealed by histological examination may indicate that biofilm formation leads to an inef-

Водяник А.А. arkadiythe1@gmail.com fective immune response, which in turn leads to increased secondary alteration.

Conclusions. Biofilm formation is an important factor in the pathogenicity of microorganisms, which affects the course of acute pyelonephritis. 
ВСТУП. Інфекція сечових шляхів (ІСШ) є однією з найрозповсюдженіших інфекційних захворювань, що вражають людей будь-якого віку та статті. Незважаючи на гетерогенність хворих, особливу групу складають діти - у даної групи пацієнтів ІСШ може призводити до рубцювання паренхіми нирки, в результаті чого може спостерігатися зниження функції нирки, протеїнурія, гіпертензія та ниркова недостатність [1].

На даний момент, одним з основних факторів, що грає роль в переході гострих форм інфекцій в хронічні, відводять бактеріальним біоплівкам [2]. Окрім цього біоплівкоутворення є важливим фактором патогенності, який забезпечує захист мікроорганізмів від імунної відповіді. Поодинокі дослідження демонструють, що бактеріальні біоплівки змінюють перебіг запального процесу, наприклад у ранах кінцівок [3].

МЕТОЮ нашої роботи було обрано дослідження морфологічних змін при гострому пієлонефриті в залежності від здатності до формування біоплівки штамами бактерій.

МАТЕРІАЛИ І МЕТОДИ. Дослідження проводилося на базі кафедри мікробіології, вірусології та імунології, кафедри гістології, цитології та ембріології та кафедри педіатрії №4 Національного медичного університету імені О.О. Богомольця.

Для проведення дослідження з зразків сечі пацієнтів, що хворіли на гострий пієлонефрит було виділено двадцять клінічних штамів бактерій (титр при виділенні $10^{5}-10^{6}$. Була перевірена здатність клінічних штамів бактерій до формування біоплівок методом мікротитрувальних планшетів [4]. За результатами інтенсивності біоплівкоутворення було відібрано два ізоляти E.coli. Ізолят E.coli P3 не формував біоплівок in vitro (показник біоплівкоутворення $=0,387$; при розмірі біоплівки $<0.4$, біоплівка вважається відсутньою [5]), ізолят E.coli P16 формував сильну біоплівку (показник біоплівкоутворення $=0,676$; при розмірі біоплівки $>0.5$, біоплівка вважається сильною).

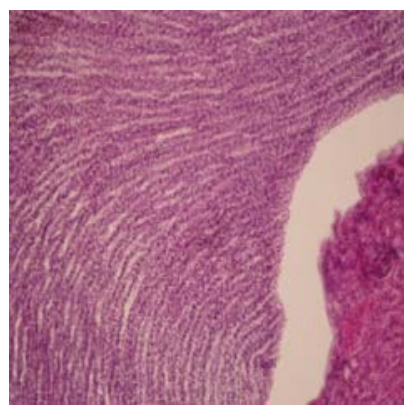

A

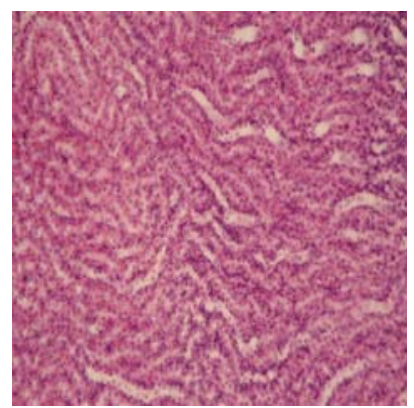

B

Ізоляти E.coli P3 та E.coli P16 були культивовані у м'ясо-пептонному бульйоні протягом 24 годин при температурі 37,0 С, та використовувалися для моделювання гострого пієлонефриту.

Для моделювання гострого пієлонефриту були відібрані 24 самки безпородистих білих лабораторних мишей віком 6-8 тижнів, вагою $25 \pm 5$ г. Лабораторні миші були поділені на три групи: група №1 «гострий пієлонефрит викликаний збудником 3 низькою здатністю до формування біоплівок in vitro» (8 мишей); група №2 «гострий пієлонефрит викликаний збудником з високою здатністю до формування біоплівок in vitro» (8 мишей); група №3 «контроль», яка складалася з восьми здорових мишей.

Гострий пієлонефрит моделювався висхідним шляхом за стандартною методикою [6]. Знеболювання проводилося тіопенталом натрію, після чого сеча з сечових міхурів мишей евакуйовувалася шляхом натискування, у просвіт уретри вводився поліетиленовий гнучкий катетер діаметром 0,5 мм та у групі № 1 вводилося 0,05 мл добової бульйонної культури E.coli Р3 у титрі 108 , у групі №2 вводилося 0,05 мл добової бульйонної культури E.coli P16 у титрі 108 , у групі №3 вводилося 0,05 мл стерильного фізіологічного розчину.

Гістологічний матеріал, у вигляді нирок тварин, забирався на 7 день моделювання гострого пієлонефриту. Тканини фіксувалися у $10 \%$ розчині формальдегіду, були дегідратовані у градієнтних розчинах етанолу (30-100\%) та забарвлені гематоксилін-еозином. Гістологічні зрізи аналізувалися на світловому мікроскопі зі збільшеннями об'єктиву $(\mathrm{x} 4-\mathrm{x} 40)$

РЕЗУЛЬТАТИ. При аналізі контрольних гістологічних зрізів (зображення 1-4) у всіх вісьмох зразках була виявлена нормальна структура нирки. Візуалізувалася кіркова та мозкова речовина нирки у співвідношенні 1/2, була відсутня лейкоцитарна інфільтрація та інші можливі ознаки запалення.

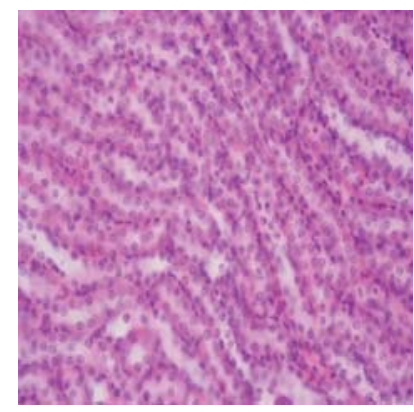

C

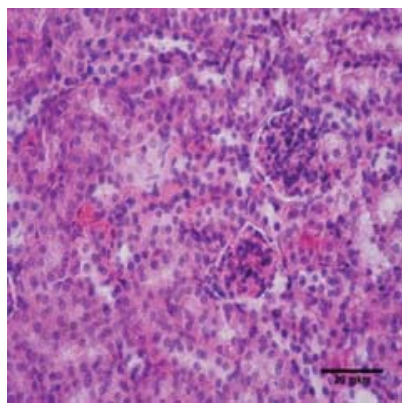

D

Зображення 1. Паренхіма нирки. Контрольний зразок (А - х10; В - х20; C - x40; D - x40).

Дослідження зразків з групи №1, де пієлонефрит був змодельований штамом з відсутньою здатністю до біоплівкоутворення, продемонструвало наявність лейкоцитарної інфільтрації у мозковому шарі нирки у всіх досліджуваних зразках (3о- браження №2 A, В) , у 6 зразках (75\%) у паренхімі нирки відмічався значний набряк строми у мозковій речовині нирки (Зображення №2 C, D, Е), що свідчить про наявність гострого запалення та вираженої ексудації. 


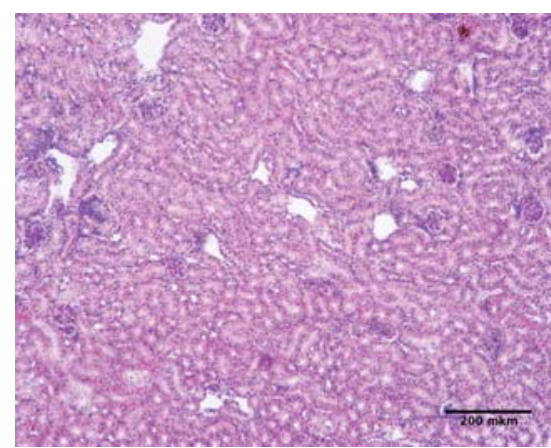

A

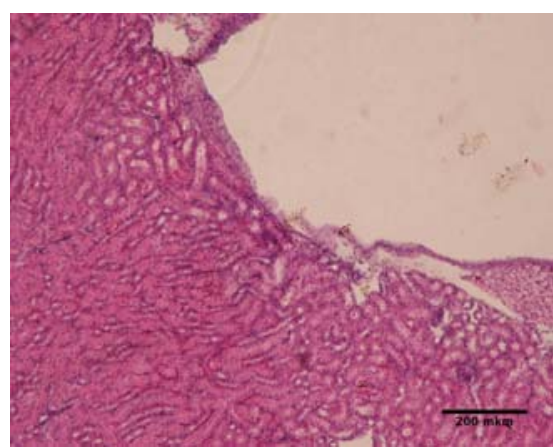

$\mathbf{B}$

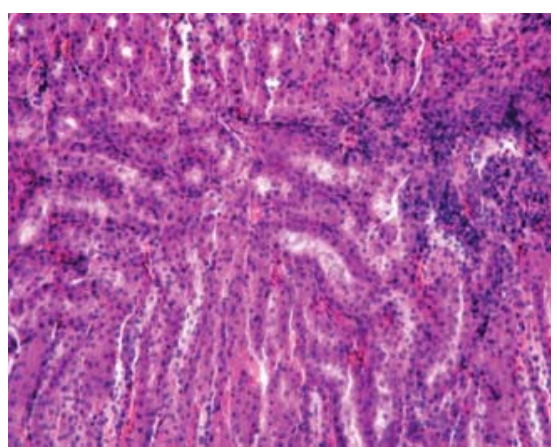

C

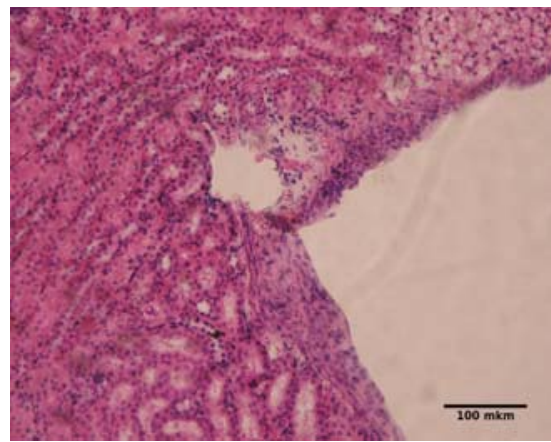

D

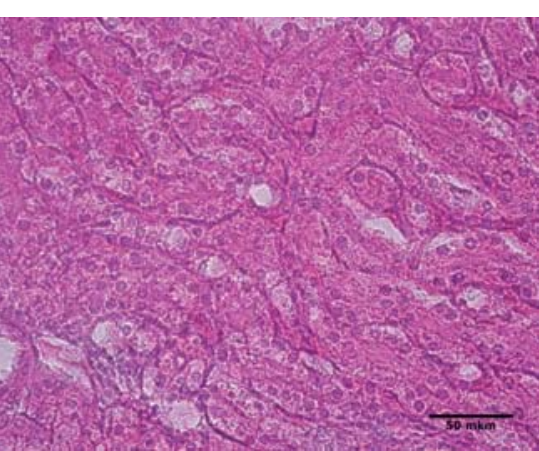

$\mathbf{E}$

Зображення 2. Паренхіма нирки. Група №1 (А - х10; В - х10; C - х20; D - x20; E - х40).

Оцінка зрізів у групі №2, де гострий пієлонефрит був змодельований клінічним штамом 3 сильною здатністю до плівкоутворення продемонструвала наявність вираженої лейкоцитарної інфільтрації у мозковій речовині в усіх зразках, у 4 зразках (50\%) лейкоцитарна інфільтрація спостері- галася й у кірковому шарі. У всіх 8 зразках спостерігався набряк інтерстицію, окрім цього у 7 (87,5\%) досліджуваних зразках були наявні екстравазати (Зображення №3 D, F, G, H). Загалом гістологічна картина у всіх зразках у групі №2 свідчила про інтенсивне запалення паренхіми нирки.

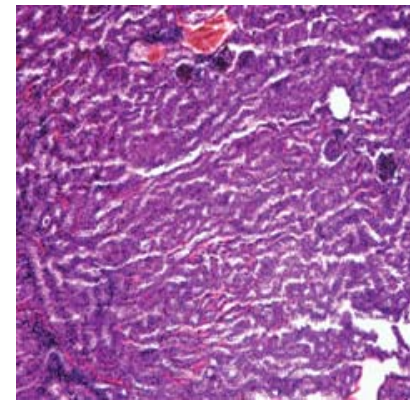

A

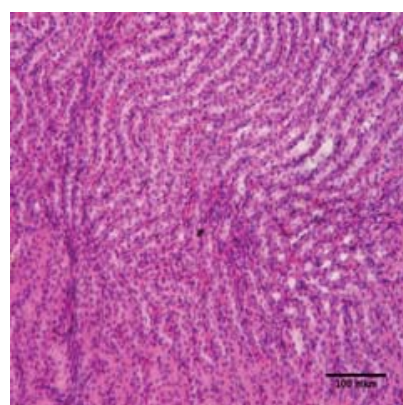

E

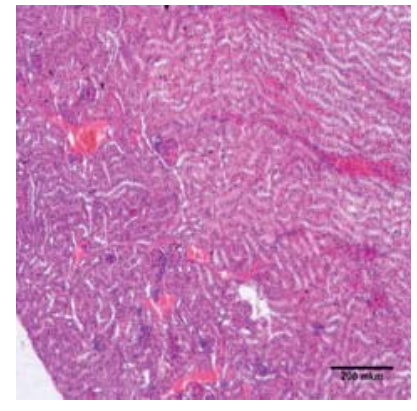

B

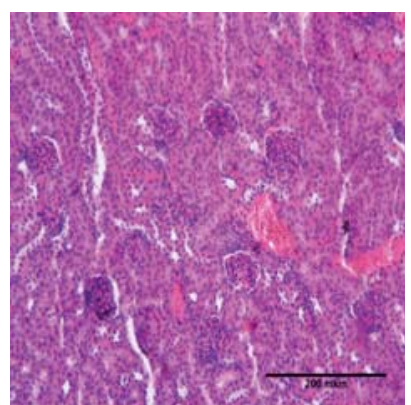

F

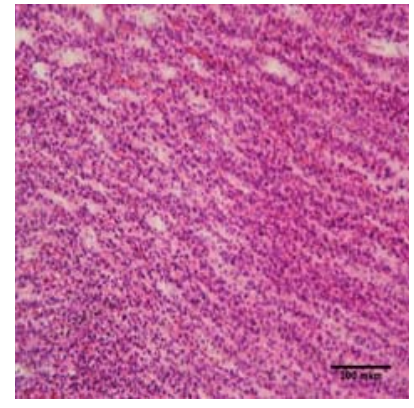

C

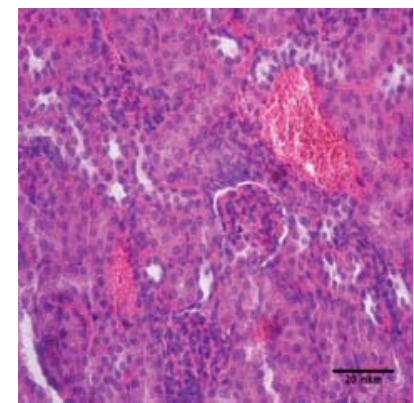

G

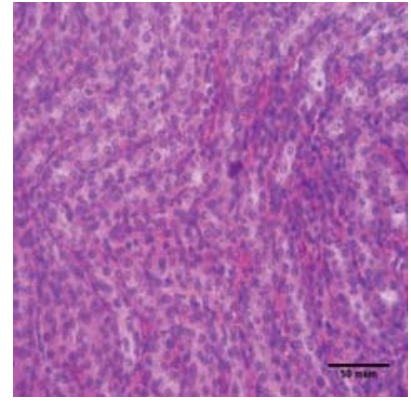

D

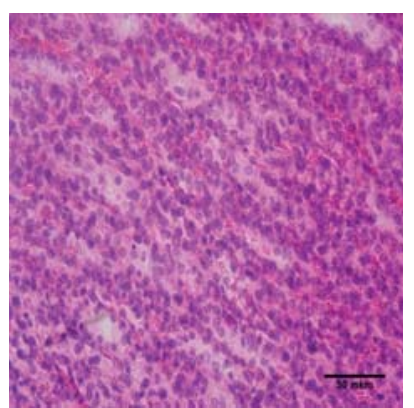

$\mathbf{H}$

Зображення 3. Паренхіма нирки. Група №2 (А - х10; В - х10; С - х20; D - х20; Е - х20; F - x20 ;G). 
ОБГОВОРЕННЯ. Здатність бактерій формувати біоплівки як та абіотичних так і на поверхні епітелію дозволяє мікроорганізмам збільшувати свою резистентність до антибактеріальних препаратів, а також до дії факторів імунітету макроорганізму [7]. Біоплівка дозволяє мікроорганізмам уникати фагоцитозу, активація компліменту відбувається на поверхні плівки і не руйнує мікроорганізми [8]. Дані гістології свідчать, що у групі №2 спостерігається набагато інтенсивніше запалення ніж у групі №1 у всіх порівнювальних зразках, хоча гострий пієлонефрит змодельований клінічними ізолятами одного виду - E.coli.

Можливим механізмом, який пояснює представлені зміни є процес підвищеної вторинної альтерації у вигляді гіперінфільтрації лейкоцитами, вираженого набряку і наявності екстравазатів, який виникає внаслідок неуспішного фагоцитозу, через формування біоплівки. Персистенція бактерій і неефективна імунна відповідь призводить до накопичення біологічно активних речовин та медіаторів запалення у місці перебування мікроорганізмів, що збільшує проникність судин і призводить до посиленої ексудації.

Виражений запальний процес у паренхімі нирки та альтерація тканин може призвести до збільшення кількості сполучної тканини та склерозу у короткі строки, що у свою чергу призведе до втрати функції нирки

ВИСНОВКИ. Модель гострого висхідного пієлонефриту у мишей є адекватною для моделювання гострого пієлонефриту та дозволяє оцінити гістологічні зміни, які при ньому виникають.

При гострому пієлонефриту викликаним клінічним ізолятом з сильною здатністю до біоплівкоутворення наявна виражена лейкоцитарна інфільтрація у кірковому та мозковому шарі нирки, разом з поширеними екстравазатами у порівнянні з гострим пієлонефритом, що викликаний штамом 3 відсутньою здатністю до біоплівкоутворення, де відмічалася лише лейкоцитарна інфільтрація та набряк строми.

Біоплівкоутворення важливий фактор патогенності мікроорганізмів, який впливає на перебіг гострого пієлонефриту та може обумовлювати несприятливий прогноз.

\section{ЛІТЕРАТУРА:}

1. Peters $C$. Vesicoureteral reflux associated renal damage: congenital reflux nephropathy and acquired renal scarring / C. Peters, G. Rushton. // J Urol.. - 2010. - №184. - C. 273.

2. Childhood urinary tract infections as a cause of chronic kidney disease / J.Salo, R. Ikäheimo, T. Tapiainen, M. Uhari. // Pediatrics.. - 2011. №128. - C. 840.

3. Percival S. Biofilms and Wounds: An Overview of the Evidence. Advances in Wound Care / S. Percival, S. McCarty, B. Lipsky. // New Rochelle. - 2015. - №4. - C. 373-381.

4. Merritt J. H., Kadouri D.E., O’Toole G.A. Growing and Analyzing Static Biofilms //CurrProtoc in Microbiol. Authormanuscript- 2005.- Chapter 1. - Unit - 1B.1.

5. Quantification of biofilm in microtiter plates: overview of testing conditions and practical recommendations for assessment of biofilm production by staphylococci / [S. Stepanović, D. Vuković, V. Hola та ін.]. // APMIS. - 2007. - №115. C. 891 .

6. Gupta R. An Ascending Non-Obstructive Model for Chronic Pyelonephritis in BALB/c Mice / Gupta R. // J Med Microbiol. - 1995. - №43. C. 33-36.

7. Окулич В. К. Роль микробных биопленок в патогенезе инфекционных процессов на современном этапе / В. К. Окулич, Ф. В. Плотников, А. А. Кабанов. // Иммунология, аллергология, инфектология. - 2012. - С. 70-82.

8. Чеботарь И. В. Механизмы антибиопленочного иммунитета / И. В. Чеботарь. // Вестник Российской Академии медицинских наук. 2012. - C. 22-29.

Надійшла до редакиії 20.06.2017 Прийнята до друку 01.08.2017 